Ghada Tayem*

\title{
Does Foreign Ownership Increase Firms' Productivity? Evidence from Firms Listed on Amman Stock Exchange
}

\begin{abstract}
The purpose of this paper is to investigate the impact of foreign ownership on the production efficiency of firms listed on the Amman Stock Exchange using hand-collected, firm-level data. Arab countries have been performing poorly in attracting foreign direct investment (FDI) inflows in comparison to other developing countries, and hence, they may be missing out on growth and development opportunities. Jordan, however, has been one of the most successful Arab countries in attracting FDI inflows relative to its economic size. Therefore, Jordan offers an ideal setting to examine the benefits of foreign ownership in the region. However, this study fails to find evidence supporting the notion that foreign ownership enhances production efficiency. This finding calls into question the economic viability of investment incentives designed to attract foreign investors.
\end{abstract}

Keywords: foreign ownership, knowledge transfer, FDI motivation, total factor productivity, labour productivity, MENA region

JEL Classification: C42, F21, F23, G32

\section{Introduction}

Jordan, as many other Arab countries, adopted structural adjustment programmes (SAPs) under the guidance of the World Bank with the expectations that liberalizing, restructuring and opening the Jordanian economy will bring enormous gains, including updating and improving the country's industrial base and technologies. ${ }^{1}$ The implementation of the SAPs accelerated in the late 1990s

1 For an overview of the history and impact of IMF and World Bank intervention programmes in Jordan, see Harrigan, El-Said, and Wang (2006) and Harrigan and El-Said (2010).

*Corresponding author: Ghada Tayem, Department of Finance, School of Business, The University of Jordan, Amman 11942, Jordan, E-mail: g.tayem@ju.edu.jo 
and prompted the adoption of friendly foreign-ownership legislative environment and the privatization of some of the largest state-owned enterprises. ${ }^{2}$ As a result, foreign ownership of firms listed on the Amman Stock Exchange (ASE) has increased substantially. This paper attempts to evaluate the theoretically anticipated gains of foreign ownership in terms of improving the efficiency of firms' productivity. However, using a production function framework, this study fails to find evidence on improvements of the production efficiency for firms with foreign ownership. Multinational enterprises (MNEs) acquired well-established Jordanian companies, and hence, once the estimation method applied in this study controls for the unobservable firm fixed effects and selection bias, productivity gains from foreign ownership becomes statistically insignificant. This result indicates that multinationals acquired Jordanian firms to exploit these companies' advantages rather than their own technological advantages which resulted in little or no knowledge transfer from the multinationals to their Jordanian affiliates.

Foreign investment can have an important impact on domestic firms' productivity growth and technologies. Multinationals arguably possess a technological advantage (Hymer 1976) and hence their presences in a host market can contribute to knowledge transfer and diffusion in that market directly or through spillover effects. MNEs directly transfer knowledge to their affiliates by providing them with advanced machinery and equipment, by implementing updated production processes and by introducing new products (Konings 2001). In addition, implementing new technologies requires labour training which in turn improves labour skills and enhances efficiency (Greenaway, Upward, and Wright 2002). Also, MNEs bring new and efficient styles of management, marketing, governance and accounting (Fu 2008; Konings 2001). Hence, domestic firms can acquire new knowledge, and consequently improve their productivity, by altering their ownership structures to include foreign investors.

However, the extent and nature of benefits arising from the transfer of knowledge from MNEs to their affiliates depend on a number of important factors, including the host economy's local conditions and the quality and motivation of the foreign investment. The extant literature suggests that positive

2 For example, Jordan enacted the "Investment Promotion Law of 1995"; streamlined the procedures of registering new companies under the "Corporate Law of 1997"; enacted property right protection laws such as the "Patent Law of 1999" and "Trade Names Law of 2003"; and enacted competition laws such as the "Unfair Competition and Trade Secrets of 2000" and "Competition Law of 2004". For a review of legislative changes in Jordan see Kanaan and Kardoosh (2005). For a critique of newly-enacted property right protection laws see El-Said and El-Said (2005). 
externalities in a host market created by foreign ownership are conditioned on threshold effects such as domestic level of human capital and overall quality of the market's institutions (Girma 2005; Alfaro, Kalemli-Ozcan, and Sayek 2009). ${ }^{3}$ One relevant aspect of institutional quality to this study is the degree of financial development. Jordan, however, ranks among the top of Arab countries in terms of bank development indicators with good scores in private credit to GDP and size of bank assets (Omran and Bolbol 2003; Krogstrup and Matar 2005). In addition, the ASE is considered a well-developed market compared to other markets in the Middle East and North Africa (MENA) region (Krogstrup and Matar 2005). For example, Lagoarde-Segot (2009) reports that the ASE displays low market volatility and low market illiquidity in comparison to 28 emerging markets.

Another area of research investigates the confounding influences of the quality and motivation of foreign investment on the anticipated productivity gains. For example, technology transfer is viable when a multinational firm sets up an affiliate to take advantage of its unique firm-specific assets while at the same time protecting its propriety knowledge through its ownership of the affiliate (Dunning 1993; Gorg and Greenaway 2004). However, the multinational presence is not expected to induce technology transfer if the foreign investment is driven by the multinational's incentive to have access to new technology in the host market (Driffield and Love 2007). In addition, an observed positive association between foreign presence and high productivity can be explained by the MNE acquiring strategy under which it targets well-performing domestic firms (Evenett and Voicu 2001; Arnold and Javorcik 2009; Karpaty 2007). This paper fits the most into this line of research as it examines the impact of foreign ownership on the productivity of Jordanian firms, with a focus on dealing with the unobserved firm heterogeneity and self-selection bias. MNEs are likely to target Jordanian companies with unique advantages such as control over natural resources, large market shares and access to local and regional markets. These advantages are also likely to be correlated with high production efficiency. If MNEs acquired well-performing Jordanian firms to exploit these companies' advantages, then once the firm's fixed effects and selection bias are controlled for, the positive impact of foreign ownership on productivity becomes insignificant.

Examining the gains of productivity in the Arab region is interesting because Arab countries have been performing poorly in attracting FDI inflows (Sadik and Bolbol 2001; Omran and Bolbol 2003; Krogstrup and Matar 2005). Table 1 reports FDI inflows to developing countries grouped by region. ${ }^{4}$ This table shows that

3 For a review of the literature, see Blomström and Kokko (2003).

4 Regions and countries within each region are based on the classification by the World Bank. 
Table 1: Foreign direct investment inflows by region.

\begin{tabular}{rrrrrrr}
\hline Year & $\begin{array}{r}\text { East Asia } \\
\text { and Pacific }\end{array}$ & $\begin{array}{r}\text { Europe and } \\
\text { Central Asia }\end{array}$ & $\begin{array}{r}\text { Latin America } \\
\text { and Caribbean }\end{array}$ & $\begin{array}{r}\text { Middle East and } \\
\text { North Africa }\end{array}$ & $\begin{array}{r}\text { South } \\
\text { Asia }\end{array}$ & $\begin{array}{r}\text { Sub-Saharan } \\
\text { Africa }\end{array}$ \\
\hline 1995 & 50.80 & 8.27 & 27.05 & 0.91 & 2.93 & 4.41 \\
1996 & 58.56 & 7.18 & 38.82 & 1.36 & 3.51 & 4.12 \\
1997 & 62.61 & 11.64 & 60.29 & 1.95 & 4.90 & 8.50 \\
1998 & 57.85 & 11.25 & 68.87 & 2.64 & 3.55 & 6.88 \\
1999 & 50.39 & 9.95 & 78.98 & 1.91 & 3.08 & 8.95 \\
2000 & 45.19 & 9.06 & 73.68 & 3.92 & 4.37 & 6.58 \\
2001 & 48.93 & 14.67 & 67.24 & 3.04 & 6.15 & 14.04 \\
2002 & 59.37 & 12.88 & 52.59 & 8.06 & 6.77 & 11.16 \\
2003 & 59.34 & 17.79 & 40.38 & 10.26 & 5.46 & 13.65 \\
2004 & 77.77 & 30.03 & 59.27 & 10.55 & 7.82 & 11.31 \\
2005 & 136.25 & 49.50 & 67.28 & 18.22 & 10.84 & 18.74 \\
2006 & 162.12 & 86.50 & 66.16 & 30.47 & 25.81 & 15.92 \\
2007 & 209.30 & 158.78 & 112.92 & 33.66 & 32.47 & 28.73 \\
2008 & 226.49 & 165.96 & 121.65 & 35.61 & 50.89 & 40.22 \\
2009 & 189.90 & 51.09 & 71.88 & 29.22 & 39.58 & 35.22 \\
2010 & 320.09 & 23.55 & 111.05 & 25.87 & 31.21 & 29.61 \\
2011 & 386.50 & 74.45 & 146.13 & 16.16 & 40.42 & 40.90 \\
\hline
\end{tabular}

Note: This table reports FDI inflows to developing countries grouped by region. Countries in each region are classified by the World Bank. Data is obtained from the World Bank Development Indicators. Figures are in thousands of millions of US dollars.

FDI inflows have been increasing steadily in all regions in the past two decades except for the years around the financial crisis. However, the size of FDI inflows varies greatly across the different regions of the world. The MENA region in particular has received the lowest amount of FDI inflows compared to developing countries in all regions in almost all years in the period 1995-2011. ${ }^{5}$ Also, the size of FDI inflows received by the MENA region in 2011, the start of the Arab spring, dropped to nearly half the average of the previous five years. Although it is early to conclude that this decrease in FDI inflows will persist, the political unrest in the region suggests that the drop in FDI inflows may continue for the next few years.

Some observers believe that countries in the MENA region are missing out on the anticipated gains of foreign ownership in terms of acquiring new technologies and on improving their firms' production efficiency (Sadik and Bolbol 2001; Omran and Bolbol 2003; Krogstrup and Matar 2005). This is

5 This observation is valid even after taking the size of region into account. 
especially relevant given that the empirical evidence from an ample number of developing and transition economies indicates that there is a positive impact of foreign participation on a firm's productivity (Aitken and Harrison 1999; Chudnovskya, Lópeza, and Rossia 2008; Damijan et al. 2003; Smarzynska-Javorcik 2004; Fu 2008; Liu and Wang 2003). This evidence is fairly robust to the choice of economic regime, time period, and method of estimation. $^{6}$

In order to encourage FDI many Arab countries, including Jordan, have adopted investment incentive programmes (IIPs) that offer tax holidays and/ or tax and tariff reductions. ${ }^{7}$ However, these investment incentives are costly and are economically justifiable only when the gains of foreign investments exceed the costs of investment incentives. For example, tax holidays and tax reductions result in a substantial decrease in tax revenues (Clark, Cebreiro, and Bohmer 2007). If that decrease in tax revenue is not offset by gains from new capital investments, induced by the incentive programme, the government may cut its expenditures or raise taxes elsewhere. This in turn can have an immediate negative impact on the economic conditions of the public, especially low income households (Chen 2004). In addition, the incentive programme may distort the incentives of non-recipient firms and hence allocate the country's resources inefficiently (Clark, Cebreiro, and Bohmer 2007). Also, investment incentives can redistribute income from host countries to MNEs especially when countries are competing for FDI (Gorg and Greenaway 2004). Therefore, productivity gains of foreign ownership must be large enough to justify these costly incentives. The analysis presented in this paper evaluates empirically the productivity gains resulting from foreign ownership by employing a productivity function with a technological innovation term using a sample of manufacturing and mining companies listed on the ASE. The empirical findings indicate that the productivity of companies with foreign ownership is not significantly different from their domestic counterparts implying that Jordanian firms are not gaining from foreign ownership. Hence, the analysis presented in this paper questions the financial viability of Jordan's investment incentive programme designed to encourage foreign direct investments (FDIs).

\footnotetext{
6 Although the evidence on the impact of foreign participation on the acquired firm's productivity is fairly robust, the evidence on spillover effects resulting from foreign presence is mixed. For a comprehensive review and meta-regression analysis, see Wooster and Diebel (2010).

7 An overview of Jordan's investment incentive program is presented in Appendix 1.
} 
In this paper I focus on the case of Jordan because of various reasons. First, Jordan has been receiving large amounts of FDI inflows as a percentage of its GDP compared to other Arab countries as indicated by figures presented in Table 2.

In addition, FDI inflows to Jordan translate into a large contribution of foreign ownership in the number of employment, sales, market values and subscribed shares in listed Jordanian companies. The first four columns in Table 3 indicate that the contribution of firms with foreign ownership to total employment is $61 \%$, to sales is $76 \%$, to market value is $83 \%$ and to subscribed shares is $64 \%$. In the next four columns I compute more conservative contributions based on the equity holding of firms with foreign ownership. However, firms with foreign ownership still account for a large contribution of employment, sales, market value and subscribed shares of $25 \%, 27 \%, 47 \%$ and $30 \%$, respectively.

Second, the results and conclusions of this study are useful in drawing policy implications not only for Jordan but also for other Arab countries. This is because Jordan shares with Arab countries similar market characteristics. The manufacturing sectors in Arab countries are labour-intensive and consumeroriented with their exports comprising mainly of natural resources. The final motivation for the use of Jordan relates to data availability. Foreign ownership data is publicly available for Jordanian listed companies and hence it allows the study of the impact of FDI on firm's productivity using firm-level data. The use of firm-level data is advantageous since the aggregation of data over economies results in a substantial loss of information (Damijan et al. 2003).

\section{Research Design}

\subsection{Hypothesis Development}

It is widely accepted that FDIs as well as trade and international licensing agreements are the main three principal channels of global technology transfer (Eaton and Kortum 1996; Grossman and Helpman 1993; Feenstra, Markusen, and Zeile 1992; Clerides, Lach, and Tybout 1998). However, this paper focuses on FDI since it is potentially the most important international vehicle of technology transfer. FDI in comparison to trade can be more efficient in transferring technology because foreign investors transfer technology directly to the affiliates under their ownership and control (Konings 2001; Hanousek, Kocenda, and Maurel 2011). In addition, the latest and most valuable technologies are not available through international licensing agreements (Damijan et al. 2003). 


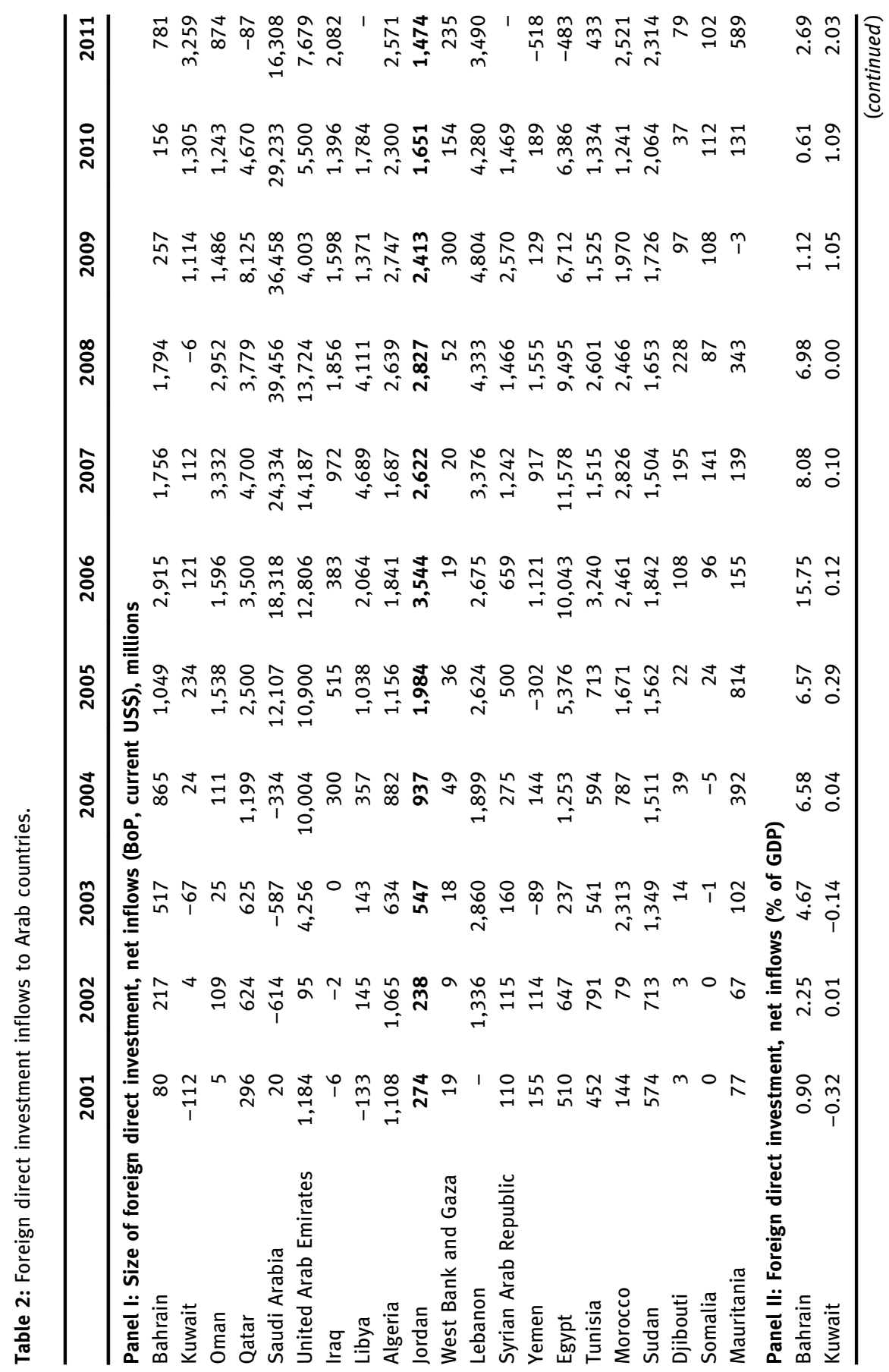




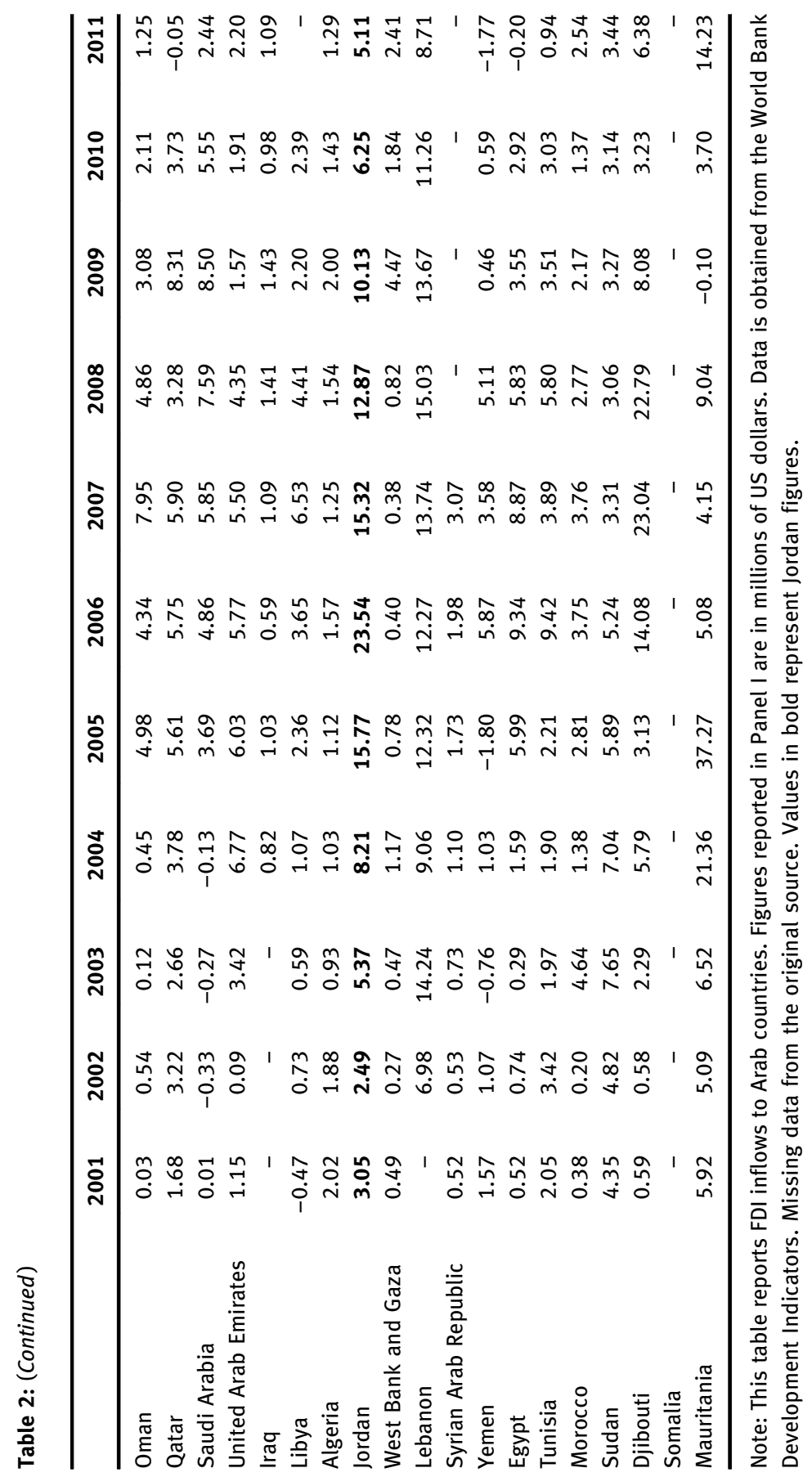




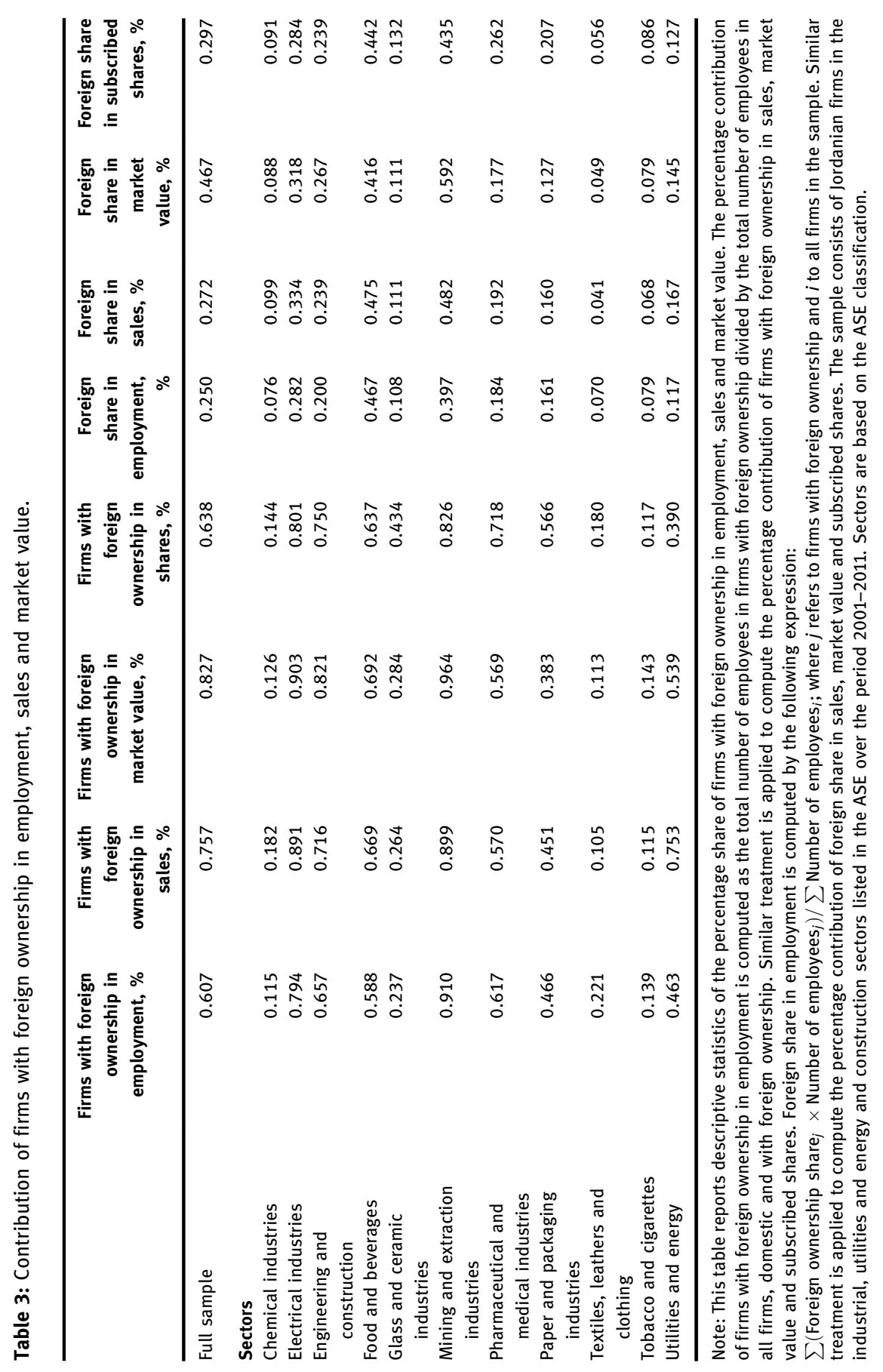


Finally, FDI results in the transfer of newer technology more quickly compared to international trade and licensing agreements (Mansfield and Romeo 1980).

The theoretical underpinning of the association between foreign ownership and productivity has its roots in Hymer (1976) and is formally theorized in Dunning (1993). Hymer (1976) suggests that foreign investors, represented by MNEs, can be an important source for technology transfer since these investors must possess certain technological advantages that allow them to succeed globally. Dunning (1993) theorizes that it is advantageous for MNEs to sets up affiliates abroad to exploit their unique firm-specific assets while at the same time protecting their propriety knowledge through their ownership of the affiliate. MNEs advantage is often of a technological nature evident by the substantial number of product innovations (Fu 2008). In addition, FDI is advantageous from the financing point of view since the acquisition of the new technology is financed by the parent company and not the affiliate (Hanousek, Kocenda, and Maurel 2011). MNEs advantage is not limited to their technological and financial advantage but also extends to their superior organizational and marketing systems, and connections to international markets (Dunning 1993). In contrast, many firms in emerging markets are characterized by obsolete machinery and outdated production methods (Konings 2001). Hence, domestic firms altering their ownership structures to include foreign investors can benefit from knowledge transfer, which in turn, can lead to an increased productivity.

Based on the theoretical motivation discussed above, one would expect foreign participation to improve the productivity of firms with foreign ownership. However, positive externalities in a host market created by foreign ownership are conditioned on threshold effects such as domestic level of human capital and overall quality of the market's institutions (Girma 2005; Alfaro, Kalemli-Ozcan, and Sayek 2009; Blomström 2002; Bénassy-Quéré, Coupet, and Mayer 2007). In addition, FDI motivations and their linkages to productivity spillovers and competition must be accounted for when investigating FDI costs and benefits (Driffield and Love 2005). In fact, productivity gains in the host economy from FDI can be seen as a function of FDI motivation (Driffield 2001; Driffield and Love 2007). More specifically, Driffield and Love (2007) hypothesize that when FDI is driven by technology sourcing and the receiving economy has lower labour costs relative to the FDI source country, the host economy would experience negative effects due to market stealing effect. Furthermore, and in line with this argument, the evidence indicates that FDI motivations determine the effect of FDI on export intensity in the host economy (Franco 2013). Another motive for MNEs is to acquire well-performing firms in the host country, with unique advantages that allowed them to perform well. Therefore, the positive association between foreign presence and high productivity can be 
an outcome of MNEs targeting well-performing domestic firms (Evenett and Voicu 2001; Arnold and Javorcik 2009; Karpaty 2007).

\subsection{Economic Model}

In order to test the impact of foreign ownership on a firm's productivity I employ two definitions of productivity as follows. First, I specify a production function of domestic firms over time $t$ using a standard growth accounting approach of Solow (1957). This approach has been used extensively for studying the productivity of inputs such as capital and labour. To study the impact of external technology transfer I augment the technology variables directly in the production function (Aitken and Harrison 1999; Damijan et al. 2003). Using the augmented production function enables us to study the various factors that affect productivity growth, including the technological accumulation factor. In this study, I examine the hypothesis that foreign investors facilitate technology transfer. Hence, I augment the model with a foreign ownership variable to test its impact on the technological growth of the firm.

Formally, I assume that the production process of the firm can be represented by the following production function $F$ that relates a firm's gross output to capital stock and labour:

$$
Y_{i t}=F\left(A_{i t} K_{i t}^{\alpha} L_{i t}^{\gamma}\right) ; i=1,2, \ldots, K ; t=1,2, \ldots, T
$$

where $Y_{i t}$ is the output of firm $i$ at time $t, K$ and $L$ are physical capital and labour, respectively. The term $A_{i t}$ captures differences in output across firms and over time that are not accounted for by the production inputs. Hence, this term represents the technological change in a firm and is often referred to as the total factor productivity (TFP). In order to account for factors that determine firm's productivity growth, I take logarithms and differentiate with respect to time:

$$
y_{i t}=\mathrm{TFP}_{i t}+\alpha k_{i t}+\gamma l_{i t}
$$

where lowercase letters denote logarithm of production inputs and $\alpha$ and $\gamma$ represent the elasticity of output with respect to $K$ and $L$, respectively. I assume that TFP is a function of technology transfer that occurs through strategic changes in a firm's ownership structure and of an error term, hence:

$$
\mathrm{TFP}_{i t}=f\left(Z_{i t}+e_{i t}\right)
$$

where $Z_{i t}$, for the purposes of this study, includes the term $\mathrm{FOWN}_{i t-1}$ which stands for foreign ownership. Equation [3] shows that technology can be 
transferred to domestic firms by foreign investors directly through their affiliates. This direct effect will show in affiliates as a growth in their productivity.

The second model I employ in this study utilizes a partial productivity measure, $\mathrm{LPROD}_{i t}$, in which one factor, labour, is considered. $\mathrm{LPROD}_{i t}$ is computed by taking the logarithm of the ratio of sales adjusted for the change in inventory deflated by the industrial producer price index and divided by the number of employees. Although this measure is inferior to TFP, it is useful since most industries in Jordan are labour intensive. In addition, I employ a variation of the variable $\mathrm{LPROD}_{i t}$ in which I use value added instead of output in the numerator (Tomiura 2007). Specifically, ValueAdded ${ }_{i t}$ is computed by taking the logarithm of the ratio of sales minus cost of sales deflated by the industrial producer price index and divided by the number of employees.

The final equation estimated in this study is specified as follows:

$$
\text { Productivity }_{i t}=\beta \text { FOWN }_{i t-1}+\sum_{j}^{1} \delta_{j} X_{j i t}+e_{i t}
$$

where Productivity $y_{i t}$ is estimated using $y_{i t}, \mathrm{LPROD}_{i t}$ and ValueAdded $\mathrm{A}_{i t}$ respectively, $y_{i t}$ is the output of firm $i$ at time $t, \operatorname{LPROD}_{i t}$ is the logarithm of the ratio between sales of each firm and the number of its total employees, ValueAdded $_{i t}$ is the logarithm of the ratio between the firm's sales minus its cost of sales to the number of its total employees; FOWN $\mathrm{N}_{i t}$ is the foreign ownership in the firm's equity capital, $X_{i t}$ is a vector comprising a set of control variables. Details on the operational definition of the variables are shown in Appendix 2.

\subsection{Estimation Methods}

In this study I examine the impact of foreign ownership on a firm's production efficiency using firm-level data over the period 2001-2011 for an unbalanced panel of Jordanian firms. I employ panel data techniques (random or fixed effects model) that take into account the firm specific effects as my base case. Then, I employ a treatment effect procedure and a propensity matching score (PMS) technique to account for the selection bias. I assume that the error term $e_{i t}$ in eq. [4] contains both individual firm-specific effects $v_{i}$ and the usual idiosyncratic error $u_{i t}$. The individual firm-specific effects $v_{i}$ are assumed to be correlated with other explanatory variables in $X_{i t}$, which renders the OLS estimates of coefficients biased and inconsistent. To get unbiased and consistent estimates of the coefficients, eq. [4] is modified to take into account the firm's specific effects:

$$
\text { Productivity }_{i t}=\beta \mathrm{FOWN}_{i t-1}+\sum_{j}^{1} \delta_{j} X_{j i t}+v_{i}+u_{i t}
$$


However, eq. [4] may be subject to a selection bias. MNEs are likely to target firms and industries that are large and who already have high production efficiency (Djankov and Hoekman 2000; Evenett and Voicu 2001). Hence, foreign investment decisions are not randomly distributed or in other words, the sample is not randomly selected. If selection bias is not modelled productivity shocks may be correlated with foreign ownership leading to inconsistent and biased estimates if OLS is used. In order to correct for the selection bias problem, I apply a treatment effect model which is considered a Heckman-type model. ${ }^{8}$ In the treatment effect procedure, the bias that results from using non-randomly selected samples is dealt with as an omitted variable bias, the selection bias being the omitted variable. To correct for this bias, the selection bias is modelled by estimating the probability of treatment (the probability a firm will receive a foreign ownership conditional on its initial characteristics). Then, based on the probit results, the inverse Mill's ratios, for all observations, are calculated. A vector of the inverse Mill's ratio is then included in the second step estimations as an additional independent variable which controls for the unobserved selection bias of foreign investment decisions. Specifically, the treatment effect model is specified as follows:

$$
\begin{gathered}
\text { Productivity }_{i t}=\beta \mathrm{FOWN}_{i t-1}+\sum_{j}^{1} \delta_{j} X_{j i t}+e_{i t} \\
\text { FOWN }_{i t}^{*}=\sum_{j}^{1} \theta_{j} Z_{j i t}+\varepsilon_{i t}
\end{gathered}
$$

FOWN $_{i t}=1$ if FOWN $_{i t}^{*}>0$ and FOWN $_{i t}=0$ otherwise

In addition, I employ another estimation technique to account for the selection bias, namely the propensity score matching (PSM). The propensity score is the conditional probability of receiving treatment, where the treatment of interest is foreign participation in a domestic firm. Let $\mathrm{FOWN}_{i}$ be an indicator variable that indicates whether firm $i$ has a foreign ownership. Let Productivity ${ }_{i}{ }^{1}$ be the productivity of a firm that has a foreign ownership; and Productivity ${ }_{i}{ }^{0}$ is the unobservable, counterfactual, productivity assuming that the firm do not have foreign ownership. To estimate the counterfactual, I employ PSM to pair each firm with foreign ownership with another firm that does not. Accordingly, I

8 The original Heckman (1979) selection model and treatment effect models use two-step procedure for correcting sample selection bias. However, there is a main difference between the two types. In Heckman-type selection model, the outcome variable is observed only for a group of the population, while in a treatment effect model the outcome variable is observed for both the treated (group of interest) and untreated (control) groups. 
estimate the probability of foreign ownership (i.e. the propensity score) using the following logistic regression:

$$
\mathrm{FOWN}_{i t}^{*}=\sum_{j}^{1} \theta_{j} Z_{j i t}+\varepsilon_{i t}
$$

where $Z$ is a vector of covariates determining the foreign ownership decision. Using kernel matching, I match firms with foreign ownership to non-foreign ownership firms based on the estimated propensity scores. Kernel matching computes the distance of propensity scores of each firm with foreign ownership from all non-foreign ownership firms. Denoting firms without foreign ownership $i^{\star}$, kernel matching calculates a weighting function, $w\left(i, i^{\star}\right)$, for each firm $_{i}$ by assigning a large value of $w\left(i, i^{\star}\right)$ to an $i^{\star}$ that has a short distance in terms of propensity score from $i$, a small value of $w\left(i, i^{\star}\right)$ to an $i^{\star}$ that is a long distance in propensity score from $i$ (Guo and Frase 2009). The average treatment effect for the treated, ATT, is then:

$$
\mathrm{ATT}=\frac{1}{n} \sum\left[\text { Productivity }_{i}^{1}-\sum_{i^{*}} w\left(i, i^{*}\right) \text { Productivity }_{i}^{0}\right]
$$

\section{Data and Descriptive Statistics}

I use firm-level, hand-collected data from the Corporate Guides published by the ASE and from companies' financial statements. The data covers the period 2001-2011 for an unbalanced panel of Jordanian firms listed on the ASE in the manufacturing, utilities and construction sectors. Private companies (domestic or with foreign ownership) are not required by law to disclose financial information and hence this study is limited to companies with listed shares in the ASE. In addition, this study focuses on manufacturing, utilities and construction companies because companies in these sectors are the ones expected to benefit the most from the technology transfer through acquiring modern equipment, machinery, production processes and employee training to replace their obsolete and outdated technologies (Konings 2001). Finally, the study eliminates companies with a number of employees less than 10 (Damijan et al. 2003).

The characteristics of the sample firms are presented in Table 4. The average foreign ownership is $18.07 \%$, which indicates that foreign investors own on average $18.07 \%$ of the sample firms' equity capital. The average foreign ownership is higher than the literature's arbitrary cut-off of $10 \%$ which is assumed to represent a foreign controlling interest in the firm. At the $10 \%$ cut-off the average ownership of foreign investors increases to $35.4 \%$ of the firm's equity capital. 


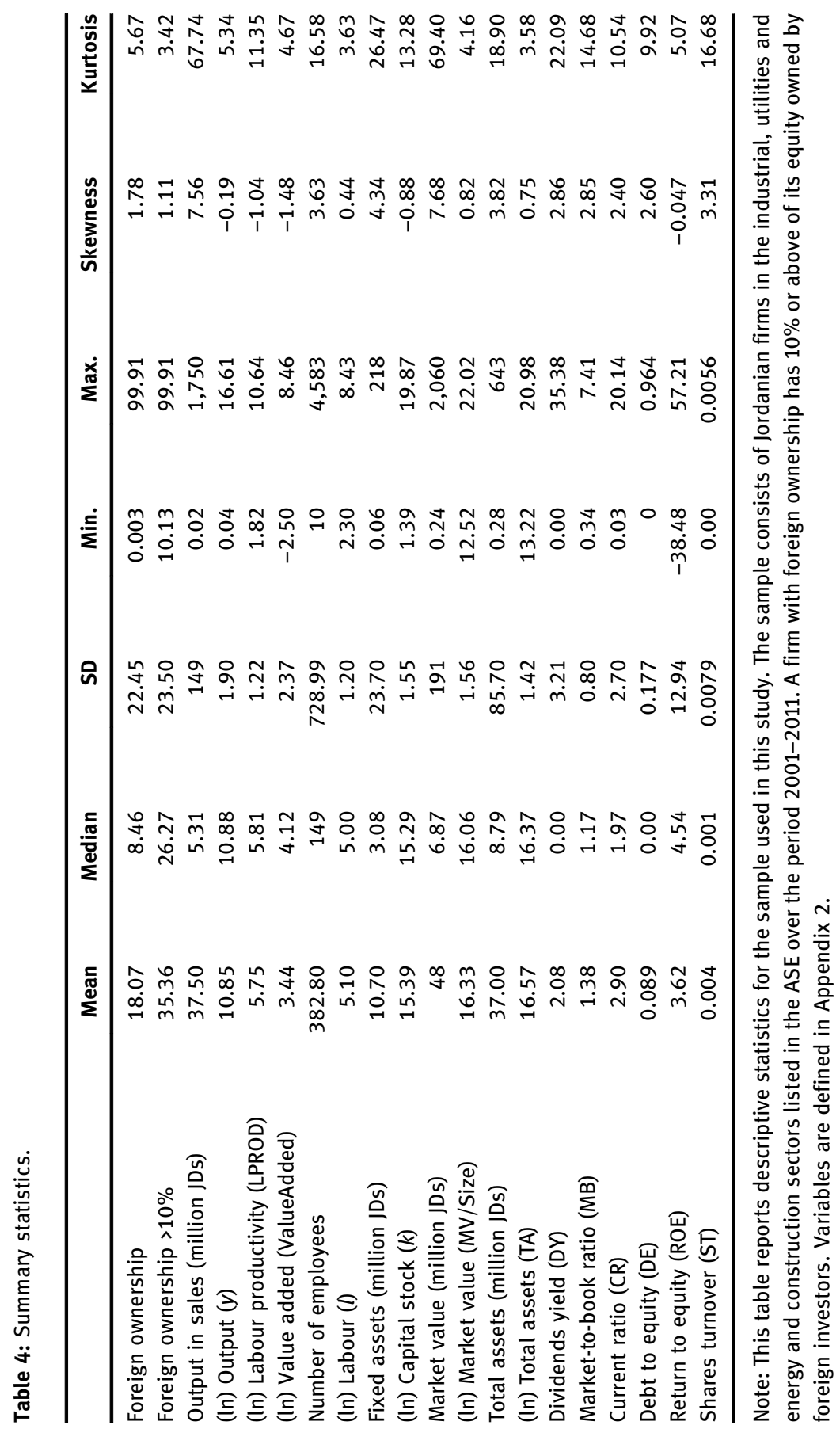


These figures confirm the earlier observation that foreign participation in Jordanian firms is large. The average deflated output produced by the sample firms during the study period is only 37.5 million JDs. In addition, half of the firmyear observations have less than 5.31 million JDs in sales. Table 4 also reports that the average number of employees, fixed assets, market value and total assets are all moderate. However, these numbers are not surprising given that Jordan's economy is relatively small with, for example, a GDP in 2011 of $\$ 28.84$ billion (the World Bank). In terms of labour productivity, the average and median labour productivity in JDs (not reported) are JDs 72,027 and JDs 33,671 per worker.

To examine if there is a significant difference in the output $y$, labour productivity (LPROD) and value added per employee (ValueAdded) between firms with foreign ownership and domestic firms I run tests on the difference in means and the Wilcoxon test. The results are reported in Table 5. Panel I reports the results of the difference in means. The results indicate that firms with foreign participation have significantly larger output $y$ and ValueAdded. However, the labour productivity LPROD is not significantly different between firms with foreign ownership and domestic firms. Table 5, Panel II reports the Wilcoxon test. Similar to the previous results, the Wilcoxon test is significant for $y$ and ValueAdded but not LPROD.

Table 5: Univariate analysis.

\begin{tabular}{lrrr}
\hline & \multicolumn{1}{c}{$\boldsymbol{Y}$} & LPROD & Value Added \\
\hline Panel I: Difference in means & & & \\
Domestic firms & 10.626 & 5.695 & 3.134 \\
Firms with foreign ownership & 11.030 & 5.743 & 3.514 \\
Difference & -0.404 & -0.048 & -0.380 \\
$t$-Test & -2.706 & -0.512 & -1.944 \\
$p$ & 0.007 & 0.609 & 0.052 \\
Panel II: Wilcoxon test & & & \\
$z$ & -2.271 & -1.475 & -2.069 \\
$p$ & 0.023 & 0.140 & 0.039 \\
\hline
\end{tabular}

Note: This table reports test results for the equality of means for $y$, LPROD and ValueAdded between firms with foreign ownership and domestic firms and results for the Wilcoxon test. The sample consists of Jordanian firms in the industrial, utilities and energy and construction sectors listed in the ASE over the period 2001-2011. A firm with foreign ownership has $10 \%$ or above of its equity owned by foreign investors. Industries are based on the ASE classification.

Finally, the correlation matrix is reported in Table 6 and indicates that $y$, LPROD and ValueAdded are all significantly correlated with foreign ownership. 


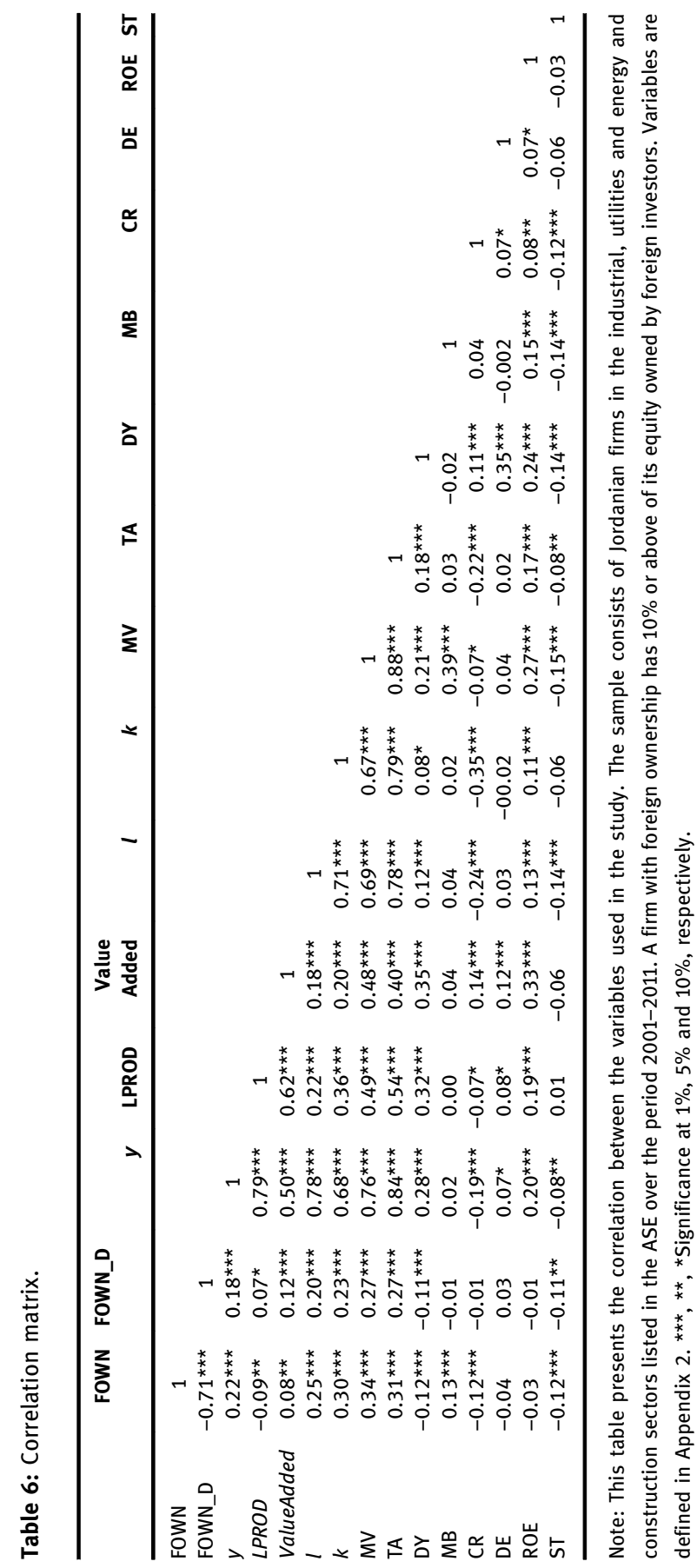




\section{Results and Analysis}

To test the impact of foreign ownership on a firm's productivity I start by estimating eq. [5]. Table 7 reports the $F$ statistic which tests the joint restriction that $v_{\mathrm{i}}$ are equal. The $F$ statistic for the estimations using $y$ and LPROD, respectively, is significant at the $1 \%$ level. Therefore, the null of no individual heterogeneity is rejected and I proceed to use panel data estimators. The fixed effects estimator treats $v_{\mathrm{i}}$ as fixed constants while in random effects estimator $v_{\mathrm{i}}$ are assumed to be drawn randomly. In this study, I do not make assumptions about the correlation between the independent variables and the unobservable effects. Hence, I estimate eq. [5] with fixed and random effects respectively and run the Hausman test and report the test results in Table 7. The Hausman test for the estimations using $y$ is significant at the $1 \%$ level and is insignificant LPROD. Therefore, I report the results of fixed and random effects.

Table 7, Panel I, reports the results of the impact of foreign participation on the firm's productivity using fixed and random effects and Tobit regression. ${ }^{9}$ The standard errors are robust and clustered by industry. The coefficient of the variable FOWN is positive with a small magnitude and statistically insignificant across all specification. This result suggests that firms with foreign ownership are not more productive compared to domestic firms. In another set of results (not reported) I account for the possibility that technology may be transferred through efficiently utilizing labour or capital. I account for this possibility by additionally including interaction terms between foreign ownership and capital FOWN $_{i t-1}{ }^{\star} k_{i t}$ and foreign ownership and labour FOWN ${ }_{i t-1}{ }^{\star} l_{i t}$ into the vector of explanatory variables. The coefficients on these interaction terms are positive but statistically insignificant. This result indicates that foreign ownership does not improve the efficiency of utilizing labour or capital. In relation to the other variables, the results are consistent with the international evidence. The coefficients of the variables $k$ and $l$ have the expected positive sign and are significant (though to various degrees). These results indicate that capital $k$ and labour $l$ contribute significantly to the output $y$.

Panel II of Table 7 reports the results of estimations similar to the ones reported in Panel I but using a subsample of 210 observations. In this subsample I include in a new variable Skilled that captures the human capital quality (Zhao

9 Tobit regression censors values at the tails of the dependent variable. I use this estimation method because the left tail of the variable ValueAdded is winsorized at an arbitrary value of 2.5. I apply this adjustment because some firm-year observations have higher cost of sales than sales. In this case, the logarithm of ValueAdded cannot be computed and the observation becomes missing unless winsorized. 


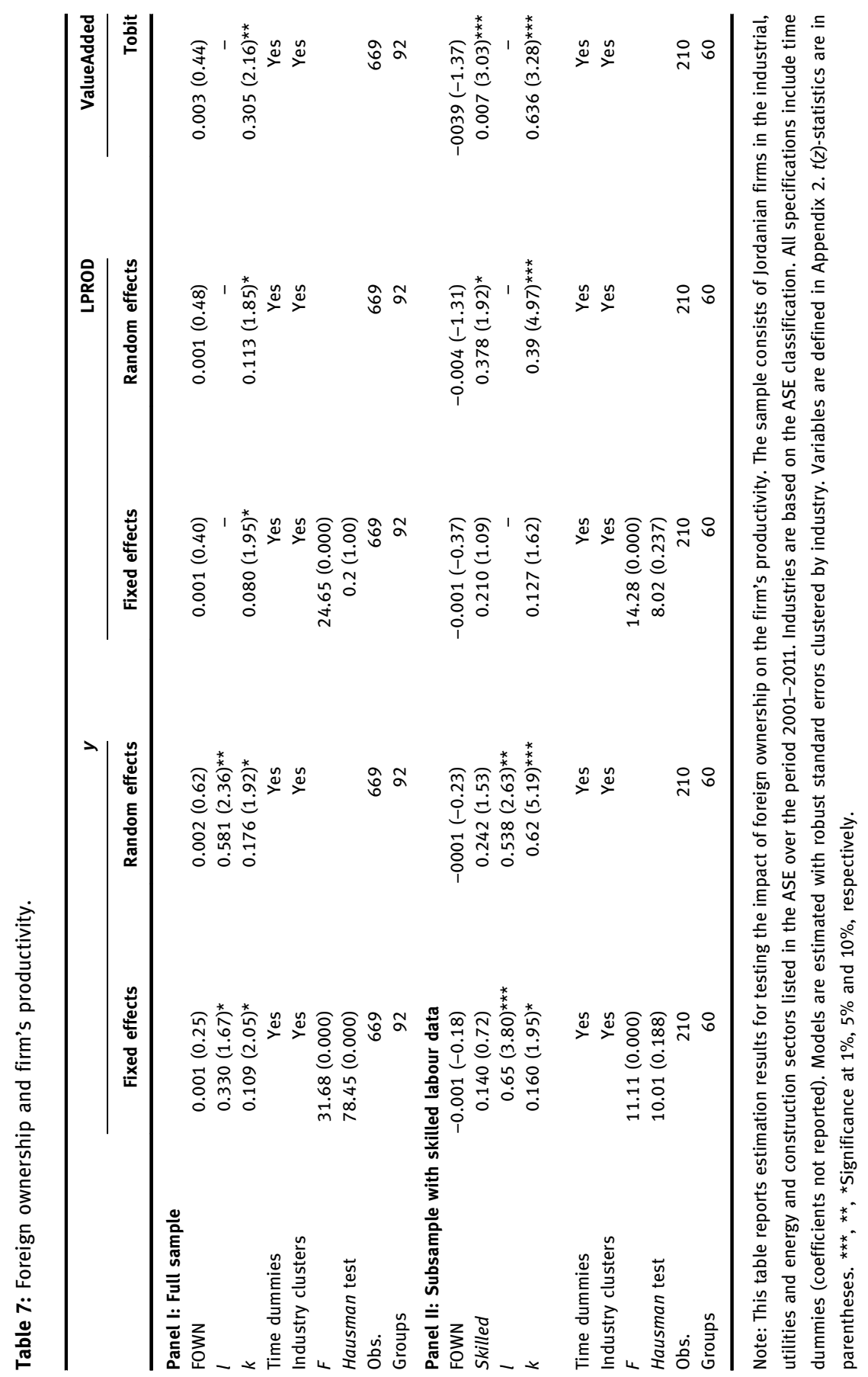


and Zhang 2010). This variable is measured as the logarithm of the ratio of skilled to total labour (Chudnovskya, Lópeza, and Rossia 2008). I collect the data from the companies' annual reports for the period 2008-2011. ${ }^{10}$ The purpose of including this variable is to take into account other factors that influence productivity. The main concern is to examine if the coefficients of the basemodel variables are stable, especially the main variable of interest, FOWN. The results reported in Panel II indicate that the coefficient of the variable Skilled is insignificant when using $y$; significant at the $10 \%$ level only in random effects when using LPROD; and significant at the $1 \%$ level but with a coefficient size close to zero when using ValueAdded. The coefficient of the variable FOWN reversed its sign to negative but still has a small magnitude and is statistically insignificant in all models. The other two variables, $l$ and $k$, have their expected signs and are significant in all models (except for $k$ in the third column). The mixed results on Skilled and the stability of other factors allow us to proceed using the base model defined in eq. [4]. ${ }^{11}$

As discussed in Section 3.3, eq. [5] may be subject to a selection bias. To account for this bias I estimate eq. [6]. In order to estimate eq. [6], I create an indicator variable, FOWN_ $D$, that takes the value of 1 if the foreign participation is above $10 \%$ and 0 otherwise. Hence, the treated group contains firms with foreign ownership and the control group contains domestic firms. The results are reported in Table 8. The reported Lambda is statistically significant which indicates that there is a selection bias, that MNEs ownership decision is not random. The decrease in the number of observation is due to missing data on the Companies Guide on some variables in the selection equation.

The main variable of interest, FOWN_ $D$, is positive but statistically insignificant. I obtain this result using $y$, LPROD and ValueAdded, respectively, as the dependent variable. This result confirms the previous one reported in Table 7 that firms with foreign ownership are not more productive compared to domestic firms. As for the other determinants of output $y$ and labour productivity LPROD, I report similar findings to the ones reported in Table 7 . The coefficients of the variables $k$ and $l$ are significant with the expected positive sign (except for $k$ in the third column). In addition, Table 8 reports the results of the selection model (the determinants of foreign ownership). It is useful to look at the significance

10 Only the annual reports of 2008 and upwards are systematically available from the ASE website.

11 In another set of results (not reported), I include an interaction term FOWN`Skilled to account for the effect of foreign investment conditional on the quality of human capital. The coefficient of the interaction term is insignificant in all models. The coefficients of the rest of the variables are qualitatively similar to the ones reported in Table 7, Panel II. 
Table 8: Foreign ownership and firm's productivity - treatment effects.

\begin{tabular}{lccr}
\hline & \multicolumn{1}{c}{$\boldsymbol{y}$} & \multicolumn{1}{c}{ LPROD } & ValueAdded \\
\hline FOWN_D & $0.013(0.18)$ & $0.006(0.07)$ & $0.113(0.60)$ \\
$l$ & $0.505(2.08)^{\star \star}$ & - & - \\
$k$ & $0.078(2.00)^{\star \star}$ & $0.049(1.87)^{\star}$ & $0.051(0.98)$ \\
Lambda & $-0.290(-3.35)^{\star \star \star}$ & $-0.204(-2.59)^{\star \star \star}$ & $-0.428(-2.54)^{\star \star}$ \\
Time dummies & Yes & Yes & Yes \\
Industry dummies & Yes & Yes & Yes \\
Observations & 614 & 614 & 614 \\
Selection equation: & & & \\
Size & & $0.865(5.26)^{\star \star \star}$ & \\
DY & & $-0.091(-1.82)^{\star}$ & \\
MB & & $-0.965(-3.52)^{\star \star \star}$ & \\
CR & & $-0.107(-2.45)^{\star \star}$ & \\
DE & & $0.002(0.73)$ & \\
ROE & & $0.001(0.48)$ & \\
ST & & $0.001(1.11)$ & \\
\hline
\end{tabular}

Note: This table reports estimation results for testing the impact of foreign ownership on the firm's productivity using treatment effects. The sample consists of Jordanian firms in the industrial, utilities and energy and construction sectors listed in the ASE over the period 2001-2011. A firm with foreign ownership has $10 \%$ or above of its equity owned by foreign investors. Industries are based on the ASE classification. All specifications include time and industry dummies (coefficients not reported). Models are estimated with robust standard errors.

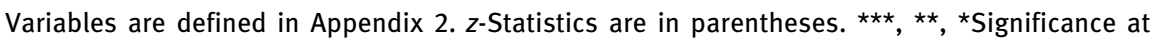
$1 \%, 5 \%$ and $10 \%$, respectively.

and the signs of the variables determining MNEs decision to participate in domestic firms. ${ }^{12}$ The findings indicate that MNEs acquire the equity of domestic firms which are large (positive and significant Size); with low payout ratio (negative and significant DY); and with undervalued assets (negative and significant $\mathrm{MB}$ ). These results are consistent with the evidence reported by Dahlquist and Robertsson (2001) and the evidence from the Jordanian market reported by Abu-Ghunmi et al. (2013). These findings support the hypothesis that foreign investors "cherry-pick" their target companies by acquiring reputable, value firms with assets that the multinational wants to control.

12 It is difficult to interpret the coefficient sizes because eq. [6] is estimated as a system of two equations (Guo, and Frase 2009). 
As a further test of the impact of foreign ownership on the firm's productivity I use PSM for pairing observations. Table 9 reports the average treatment effect for the treated, ATT. The ATT is insignificant using $y$, LPROD and ValueAdded. This finding confirms the previous results that once the unobserved heterogeneity and selection bias are controlled for, the production efficiency of firms with foreign ownership and domestic firms are not significantly different.

Table 9: Foreign ownership and firm's productivity - average treatment effect for the treated (ATT).

\begin{tabular}{llrrrr}
\hline & Sample & Treated & Controls & Difference & $t$-Statistic \\
\hline$y$ & Unmatched & 11.221 & 10.604 & $0.616^{\star \star \star}$ & $(4.20)$ \\
& ATT & 11.221 & 11.277 & -0.057 & $(-0.18)$ \\
\multirow{4}{*}{ LPROD } & Observations & 267 & 347 & & \\
& Unmatched & 5.846 & 5.732 & 0.114 & $(1.26)$ \\
& ATT & 5.846 & 6.038 & -0.192 & $(-0.97)$ \\
ValueAdded & Observations & 267 & 347 & & \\
& Unmatched & 3.671 & 3.159 & $0.512^{\star \star \star}$ & $(2.61)$ \\
& ATT & 3.671 & 3.953 & -0.281 & $(-0.67)$ \\
& Observations & 267 & 347 & & \\
\hline
\end{tabular}

Note: This table reports estimation results for testing the impact of foreign ownership on the firm's productivity using propensity score matching (PSM) for pairing observations. Matching is based on the estimates of eq. [7] that includes the following variables: size (MV); fixed assets (k); number of employees (l); dividends yield (DY); shares turnover (ST); market-to-book (MB); and current ratio (CR); and industry. The sample consists of Jordanian firms in the industrial, utilities and energy and construction sectors listed in the ASE over the period 2001-2011. A firm with foreign ownership has $10 \%$ or above of its equity owned by foreign investors. Industries are based on the ASE classification. Variables are defined in Appendix 2. $z$-Statistics are in parentheses. ${ }^{\star \star \star},{ }^{\star \star},{ }^{\star}$ Significance at $1 \%, 5 \%$ and $10 \%$, respectively.

Finally, I account for the possible endogeneity between output and inputs in the production function using system-GMM estimation method instrumented with three lags. I report the results in Table 10. The variable of interest FOWN is still of small magnitude and statistically insignificant.

\section{Conclusion}

Arab countries attract only a small fraction of the total FDI flows to developing countries. Jordan, however, have received substantial FDI flows relative to its GDP and those flows translate into a large contribution of foreign investors in the number of employment, sales, market values and equity capital in listed 
Table 10: Foreign ownership and firm's productivity - system GMM.

\begin{tabular}{lccc}
\hline & & & System GMM \\
\hline & $y$ & LPROD & ValueAdded \\
\hline Lagged_y & $0.893(24.64)^{\star \star \star}$ & - & - \\
Lagged_LPROD & - & $0.788(16.77)^{\star \star \star}$ & - \\
Lagged_ValueAdded & - & - & $0.747(18.65)^{\star \star \star}$ \\
FOWN & $0.001(0.90)$ & $0.000(0.07)$ & $-0.003(-0.50)$ \\
$l$ & $0.097(2.13)^{\star \star}$ & - & - \\
$k$ & $0.037(1.81)^{\star}$ & $0.061(3.51)^{\star \star \star}$ & $0.037(2.02)^{\star \star}$ \\
Time dummies & Yes & Yes & Yes \\
Observations & 656 & 656 & 656 \\
AR(1) $(z)$ & $(-8.43)^{\star \star \star}$ & $(-9.55)^{\star \star \star}$ & $(-7.01)^{\star \star \star}$ \\
AR(2) $(z)$ & $(1.38)$ & $(1.06)$ & $(1.04)$ \\
Sargan test $\left(x^{2}\right)$ & $(306.34)^{\star \star \star}$ & $(225.70)^{\star \star \star}$ & $(185.00)^{\star}$ \\
\hline
\end{tabular}

Note: This table reports estimation results for testing the impact of foreign ownership on the firm's productivity Using System GMM. The sample consists of Jordanian firms in the industrial, utilities and energy and construction sectors listed in the ASE over the period 2001-2011. Industries are based on the ASE classification. All specifications include time dummies (coefficients not reported). Variables are defined in Appendix 2. $z$-Statistics are in parentheses. ${ }^{\star \star *}$, **, ${ }^{\star}$ Significance at $1 \%, 5 \%$ and $10 \%$, respectively.

Jordanian companies. Based on the premise that foreign investors can transfer advanced technologies and knowledge to their affiliates in the host market at a low cost one would expect that firms acquired by foreign investors will outperform their domestic counterparts in terms of production efficiency. Using TFP, labour productivity and value added per employee as measures of productivity innovation and efficiency in a sample of Jordanian companies, I fail to find evidence on improvements of production efficiency for firms with foreign ownership. The finding of no-impact is robust using alternative estimation methods. This result contradicts the documented international evidence from other developing countries. However, this finding can be explained by the motivation of ownership of foreign investors who are targeting well-performing companies with valuable assets to be acquired under their control. The noresult finding of this study questions the value of current costly investment incentives designed to attract FDI. In addition, it points out to the complexity of realizing possible gains of foreign ownership especially in the context of a small economy. 


\section{Appendix 1: Jordan's Investment Incentives Programme}

In this appendix I describe Jordan's current investment incentives programme relevant to manufacturing and mining companies. Then I evaluate the likelihood of this programme to attract technology-based projects.

The major components of the current investment incentives programme are defined under the "Investment Promotion Law of 1995" and in "The Jordan Industrial Estate Corporation Law of 1985 ". ${ }^{13}$ Incentives are based on allowing favourable treatment of income taxes and import duty on capital goods and property taxes in specific locations (zones) and industries for a specific period of time. Manufacturing and mining companies receive favourable tax treatment under the two laws. Under "The Investment Promotion Law of 1995”, a company is eligible to receive income tax reductions and import duty exemptions. In terms of incentives related to income taxes, Jordan is divided into three development zones: A, B and C. Industry coverage varies according to zone, however, exemptions for projects in mining and manufacturing are allowed for the three zones. Qualified projects can receive a tax reduction of $25 \%$ in zone $\mathrm{A}, 50 \%$ in zone $\mathrm{B}$ and $75 \%$ in zone $\mathrm{C}$ for a period of 10 years. In terms of import duty exemptions, a project is qualified to receive duty exemptions on imported fixed assets for 3 years from the date of approval; on imported spare parts valued at $15 \%$ of the value of fixed assets up to 10 years; and on imported fixed assets in case of $25 \%$ or more expansion. Under "The Jordan Industrial Estate Corporation Law of 1985", new companies established or relocated in industrial estates receive exemption from income taxes for 2 years; tax reductions of $25 \%$, $50 \%$ and $75 \%$ if the project is located in an industrial estate in zone $\mathrm{A}$, zone $\mathrm{B}$ and zone $\mathrm{C}$, respectively, for a period of 10 ; and 10\% income tax reduction thereafter.

Tax holidays can be ineffective in attracting large-scale, long-term capital investments, which are the type of investments that can result in technology transfers and spill-overs. The Jordanian tax authority prevents qualifying firms who enjoy investment incentives from enjoying other tax benefits, namely acceleration of depreciation and carry forward operating losses (Article 5, Regulation No. 5, 2002; Article 10. C, Income Tax Law). Newly

13 In this discussion, I exclude laws specific to independent tax territories. 
established manufacturing projects invest heavily in fixed assets and hence can report large depreciation expenses if they are allowed to. In addition, manufacturing companies tend to report large operating losses at the start of their operations implying that the tax holiday may expire by the time they become profitable. Conversely, these companies are not allowed to carry forward their losses as regular businesses. Accordingly, the benefits of tax holidays can be offset by the loss of benefits from accelerated depreciation and carry forward tax provisions allowed for regular businesses. In terms of tariff reductions, the conditions on duty exemptions can be restrictive for manufacturing companies with heavy use of machinery because fixtures and replacements (expansions) are not exempted from duty unless they are valued at $15 \%(25 \%)$ or more of fixed assets. Further, Jordan's duty exemptions on imported fixed assets are not competitive with other countries in the region such as the UAE that imposes no import duty on goods used in capital investment (Chen 2004).

In terms of the Jordanian experience, FDI inflows gained momentum in late 1990s up until mid-2000s and were primarily attributed to the privatization of some of the largest Jordanian companies and, to a lesser degree, to the initiation of qualifying industrial zones (QIZs). Privatized companies are not likely to benefit from tax incentives unless they expand by investing in new large-scale projects. As discussed above, however, the value of tax benefits is not expected to be significant enough to induce investing in large-scale projects. QIZs, on the other hand, have attracted a sizable amount of FDI mainly in the textile industry (Momani 2007). Companies in the textile industry take advantage of tax incentives with little loss from relinquishing regular business tax provisions on accelerated depreciation and operating losses. However, companies in QIZs enjoy duty-free access to the US market in addition to the generous tax incentives which confounds the stand-alone impact of tax incentives. In addition, the prospect of technology transfer in companies in QIZs is questionable, since most of these companies are small scale projects that operate in low-technology, labour-intensive industries. Moreover, since textile companies invest very little in fixed assets they can reallocate to countries with more favourable conditions after the period of income holiday expires (Blomström and Kokko 2003). In conclusion, the investment incentives programme in Jordan is likely to be infective in attracting long-term, large-scale projects and the programme's ability to attract labour-intensive projects is likely to be confounded by other set of incentives. 


\section{Appendix 2: Operational Definition of the Variables}

\begin{tabular}{ll}
\hline Variable & Definition \\
\hline Foreign ownership (FOWN) & $\begin{array}{l}\text { The percentage of foreign participation in the capital of firm } i \text { at } \\
\text { time } t-1 \text {. This variable is hand collected from the Ownership } \\
\text { Statistics included in the Companies Guide issued by the ASE. }\end{array}$ \\
$\begin{array}{l}\text { Foreign Ownership Dummy } \\
\text { (FOWN_D }\end{array}$ & $\begin{array}{l}\text { An indicator variable taking the value of } 1 \text { if the foreign } \\
\text { ownership is above } 10 \% \text { for firm } i \text { at time } t-1\end{array}$ \\
Output $(y)$ & $\begin{array}{l}\text { The logarithm of sales adjusted for the change in inventory and } \\
\text { deflated by the industrial producer price index for firm } i \text { at time } t . \\
\text { Sales and inventory data are collected from the Companies Guide } \\
\text { issued by the ASE. The industrial producer price index is } \\
\text { collected from the Department of Statistics. }\end{array}$
\end{tabular}

Labour productivity (LPROD) The logarithm of the ratio between sales adjusted for the change in inventory and deflated by the industrial producer price index divided by the number of employees. Sales and inventory data are collected from the Companies Guide issued by the ASE. The industrial producer price index is collected from the Department of Statistics. The number of employees is hand collected from three sources: General Statistics included in the Companies Guide issued by the ASE; the ASE's website; and firm's financial statements.

Value added per employee (ValueAdded)

Capital stock $(k)$

Labour (l)

Size of the firm (Size)
The logarithm of the ratio between sales and cost of sales divided by the number of employees. Sales and cost of sales data are collected from the Companies Guide issued by the ASE. The number of employees is hand collected from three sources: General Statistics included in the Companies Guide issued by the ASE; the ASE's website; and firm's financial statements.

The logarithm of net fixed assets for firm $i$ at time $t$. Net fixed assets data are collected from the Companies Guide issued by the ASE.

The logarithm of the number of employees for firm $i$ at time $t$. Firms included in the analysis are the ones with 10 employees or more. The number of employees is hand collected from three sources: General Statistics included in the Companies Guide issued by the ASE; the ASE's website; and firm's financial statements.

The logarithm of the total market value of the firm. This data item is collected from the Companies Guide issued by the ASE. 
(Continued)

\begin{tabular}{ll}
\hline Variable & Definition \\
\hline Market-to-book ratio (MB) & $\begin{array}{l}\text { The ratio between sum of the market value of a firm's equity and } \\
\text { the book value of its liabilities divided by the book value of a } \\
\text { firm's assets. Relevant data items are collected from the } \\
\text { Companies Guide issued by the ASE. } \\
\text { The percentage between the dividends per share divided by the } \\
\text { price per share. Relevant data items are collected from the } \\
\text { Companies Guide issued by the ASE. } \\
\text { The ratio between current assets to current liabilities. Relevant } \\
\text { data items are collected from the Companies Guide issued by the } \\
\text { ASE. } \\
\text { The ratio between a firm's net income to its total equity. Relevant } \\
\text { data items are collected from the Companies Guide issued by the } \\
\text { ASE. } \\
\text { The number of shares traded divided by the number of } \\
\text { Shares turnover (ST) }\end{array}$ \\
$\begin{array}{l}\text { Subscribed shares. Relevant data items are collected from the } \\
\text { Companies Guide and the Statistical Bulletins issued by the ASE. }\end{array}$
\end{tabular}

Acknowledgements: I would like to thank participants at the 20th Economic Research Forum (ERF) Annual Conference and at the 17th International Economic Association World Congress for providing useful comments. I also would like to thank an anonymous referee for providing valuable comments and suggestions that greatly improved the paper. This research received financial support from the World Trade Organization (WTO) Chair program at the University of Jordan. The WTO Chair program had no involvement in the conduct of the research or the preparation of this article. All errors are my own.

\section{References}

Abu-Ghunmi, D., B. Al-Zu'bi, S. Badreddine, and S. Chaudhry. 2013. “Foreign Direct Investments in Jordan." International Journal of Business 18 (3): 255-72.

Aitken, B. J., and A. E. Harrison. 1999. "Do Domestic Firms Benefit from Direct Foreign Investment? Evidence From Venezuela.” American Economic Review 89 (3): 605-18.

Alfaro, L., S. Kalemli-Ozcan, and S. Sayek. 2009. “FDI, Productivity and Financial Development.” The World Economy 32 (1): 111-35.

Arnold, J. M., and B. S. Javorcik. 2009. "Gifted Kids or Pushy Parents? Foreign Direct Investment and Plant Productivity in Indonesia." Journal of International Economics 79 (1): 42-53.

Blomström, M. 2002. The Economics of International Investment Incentives. OECD, International Investment Incentives 165-83: OECD. 
Blomström, M., and A. Kokko. 2003. The Economics of Foreign Direct Investment Incentives. Cambridge, MA: National Bureau of Economic Research.

Bénassy-Quéré, A., M. Coupet, and T. Mayer. 2007. "Institutional Determinants of Foreign Direct Investment." The World Economy 30 (5): 764-82.

Chen, D. 2004. Reformulating the Tax Incentive Program in Jordan: Analysis and Recommendations. Toronto, Canada, International Tax Program: University of Toronto.

Chudnovskya, D., A. Lópeza, and G. Rossia. 2008. “Foreign Direct Investment Spillovers and the Absorption Capabilities of Domestic Firms in the Argentine Manufacturing Sector (1992-2001)." The Journal of Development Studies 44 (5): 645-77.

Clark, S., A. Cebreiro, and A. Bohmer. 2007. Tax Incentives for Investment - A Global Perspective: Experiences in MENA and Non-MEAN Countries. OECD, MENA-OECD Investment Programme: OECD.

Clerides, S. K., S. Lach, and J. R. Tybout. 1998. "Is Learning-by-Exporting Important? MicroDynamic Evidence from Colombia, Mexico and Morocco." Quarterly Journal of Economics 113 (3): 903-47.

Dahlquist, M., and G. Robertsson. 2001. "Direct Foreign Ownership, Institutional Investors, and Firm Characteristics." Journal of Financial Economics 59 (3): 413-40.

Damijan, J. P., M. Knell, B. Majcen, and M. Rojec. 2003. "The Role of FDI, R\&D Accumulation and Trade in Transferring Technology to Transition Countries: Evidence from Firm Panel Data for Eight Transition Countries." Economic Systems 27 (3): 189-204.

Djankov, S., and B. Hoekman. 2000. "Foreign Investment and Productivity Growth in Czech Enterprises." The World Bank Economic Review 14 (1): 49-64.

Driffield, N.. 2001. "The Impact on Domestic Productivity of Inward Investment in the UK." The Manchester School 69 (1): 103-19.

Driffield, N., and J. H. Love. 2005. "Who Gains from Whom? Spillovers, Competition and Technology Sourcing in the Foreign-Owned Sector of UK Manufacturing." Scottish Journal of Political Economy 52 (5): 663-86.

Driffield, N., and J. H. Love. 2007. "Liking FDI Motivation and the Host Economy Productivity Effects: Conceptual and Empirical Analysis." Journal of International Business Studies 38 (3): 460-73.

Dunning, J. H. 1993. Multinational Enterprises and the Global Economy. Reading, Addison Wesley.

Eaton, J., and S. Kortum. 1996. "Trade in Ideas: Patenting and Productivity in the OECD." Journal of International Economics 40 (3): 251-78.

El-Said, H., and M. El-Said. 2005. "TRIPS, Bilateralism, Multilateralism and Implications for Developing Countries: Jordan's Drug Sector.” Journal of International Economic Law 2 (1): 59-80.

Evenett, S. J., and A. Voicu. 2001. Picking Winners or Creating Them? Revisiting the Benefits of FDI in the Czech Republic. Washington, DC: World Bank.

Feenstra, R. C., J. R. Markusen, and W. Zeile. 1992. "Accounting for Growth with New Inputs: Theory and Evidence." American Economic Review 82 (2): 415-21.

Franco, C. 2013. "Exports and FDI Motivations: Empirical Evidence from US Foreign Subsidiaries." International Business Review 22 (1): 47-62.

Fu, X. 2008. "Foreign Direct Investment, Absorptive Capacity and Regional Innovation Capabilities: Evidence from China." Oxford Development Studies 36 (1): 89-110.

Girma, S. 2005. "Absorptive Capacity and Productivity Spillovers from FDI: A Threshold Regression Analysis." Oxford Bulletin of Economics and Statistics 67 (3): 281-306. 
Gorg, H., and D. Greenaway. 2004. "Much Ado about Nothing? Do Domestic Firms Really Benefit From Foreign Direct Investment?" The World Bank Research Observer 19 (2): 171-97.

Greenaway, D., R. Upward, and P. Wright. 2002. Structural Adjustment and the Sectoral and Geographic Mobility of Labour. Nottingham, UK, Research Paper Series: Globalization and Labour Markets Programme: University of Nottingham.

Grossman, G. M., and E. Helpman. 1993. Innovation and Growth in the Global Economy. Cambridge, MA: MIT Press.

Guo, S., and M. W. Frase. 2009. Propensity Score Analysis: Statistical Methods and Applications. Thousand Oaks, CA: Sage.

Hanousek, J., E. Kocenda, and M. Maurel. 2011. "Direct and Indirect Effects of FDI in Emerging European Markets: A Survey and Meta-Analysis." Economic Systems 35 (3): 301-22.

Harrigan, J. R., and H. El-Said. 2010. "The Economic Impact of IMF and the World Bank Programs in the Middle East and North Africa: A Case Study of Jordan, Egypt, Morocco, and Tunisia, 1983-2004." Review of Middle East Economics and Finance 6 (2): 1-25.

Harrigan, J. R., H. El-Said, and C. Wang. 2006. "The IMF and the World Bank in Jordan: A Case of Over Optimism and Elusive Growth." Review of International Organizations 1 (3): 263-92.

Heckman, J. J. 1979. "Sample Selection Bias as a Specification Error." Econometrica 47 (1): 15361.

Hymer, S. 1976. The International Operations of National Firms: A Study of Direct Foreign Investment. Cambridge, MA: MIT Press.

Kanaan, T., and M. Kardoosh. 2005. Law-Making for Trade Liberalization and Investment Promotion in Jordan. Bonn, Germany, Center for Development Research: University of Bonn.

Karpaty, P. 2007. "Productivity Effects of Foreign Acquisitions in Swedish Manufacturing: The FDI Productivity Issue Revisited." International Journal of the Economics of Business 14 (2): 241-60.

Konings, J. 2001. "The Effects of Foreign Direct Investment on Domestic Firms." Economics of Transition 9 (3): 619-33.

Krogstrup, S., and L. Matar. 2005. Foreign Direct Investment, Absorptive Capacity and Growth in the Arab World. Geneva, Switzerland, HEI Working Paper Series: Graduate Institute of International Studies.

Lagoarde-Segot, T. 2009. "Financial Reforms and Time-Varying Microstructures in Emerging Equity Markets." Journal of Banking and Finance 33 (10): 1755-69.

Liu, X., and C. Wang. 2003. "Does Foreign Direct Investment Facilitate Technological Progress? Evidence from Chinese Industries." Research Policy 32 (6): 945-53.

Mansfield, E., and A. Romeo. 1980. "Technology Transfer to Overseas Subsidiaries by U.S.Based Firms." Quarterly Journal of Economics 95 (4): 737-50.

Momani, B. 2007. "A Middle East Free Trade Area: Economic Interdependence and Peace Considered." The World Economy 30 (11): 1682-700.

Omran, M., and A. Bolbol. 2003. "Foreign Direct Investment, Financial Development, and Economic Growth: Evidence from the Arab Countries." Review of Middle East Economics and Finance 1 (3): 231-49.

Sadik, A. T., and A. A. Bolbol. 2001. "Capital Flows, FDI, and Technology Spillovers: Evidence from Arab Countries." World Development 29 (12): 2111-25.

Smarzynska-Javorcik, B. 2004. "Does Foreign Direct Investment Increase the Productivity of Domestic Firms? in Search of Spillovers Through Backward Linkages." The American Economic Review 94 (3): 605-27. 
Solow, R. 1957. "Technical Change and the Aggregate Production Function." The Review of Economic and Statistics 39 (3): 312-20.

Tomiura, E. 2007. "Foreign Outsourcing, Exporting, and FDI: A Productivity Comparison the Firm Level." Journal of International Economics 72 (1): 113-27.

Wooster, R. B., and D. S. Diebel. 2010. "Productivity Spillovers from Foreign Direct Investment in Developing Countries: A Meta-Regression Analysis." Review of Development Economics 14 (3): 640-55.

Zhao, Z., and K. H. Zhang. 2010. "FDI and Industrial Productivity in China: Evidence from Panel Data in 2001-06." Review of Development Economics 14 (3): 656-65. 